\title{
Rancang Bangun Alat Pendeteksi Kendaraan Dari Arah Berlawanan Pada Tikungan Tajam Berbasis Arduino UNO
}

\author{
${ }^{1}$ Ayuni Finda Rika, ${ }^{2}$ Nuzul Hikmah \\ ${ }^{1}$ Teknik Elektro, Universitas Panca Marga \\ ${ }^{2}$ Teknik Elektro, Universitas Panca Marga \\ 12ayuneeayu@gmail.com, ²n.hikmah1807@upm.ac.id
}

\begin{abstract}
Article Info
ABSTRACT

Article history:

Received January $13^{\text {th }}, 2021$

Revised January $24^{\text {th }}, 2021$

Accepted February $27^{\text {th }}, 2021$

\section{Keyword:}

Sharp bend

Ultrasonic

Arduino UNO

Copyright $@ 2021$ Jurnal JEETech.

All rights reserved.

\section{Corresponding Author:}

Ayuni Finda Rika,

Teknik Elektro, Universitas Panca Marga,

J1. Yos Sudarso 107 Pabean Dringu Probolinggo 67271

Email: ayuneeayu@gmail.com

Abstrak-Tikungan tajam adalah tikungan yang mempunyai sudut lancip dengan tingkat kesulitan saat kendaraan melintasi jalan. Pada tikungan tajam sering terjadi kecelakaan kendaraan. Kecelakan disebabkan oleh kendaraan yang melaju pada kecepatan tinggi saat akan melintas di tikungan jalan. Selain itu, pengendara juga ingin mendahului kendaraan saat akan melewati tikungan. Dengan pembuatan sistem peringatan ini diharapkan dapat mengurangi terjadinya kecelakaan pada tikungan jalan. Alat ini dapat mendeteksi adanya kendaraan dan akan memberikan peringatan berupa lampu indikator yang dikendalikan oleh mikrokontroller Arduino UNO dengan menggunakan sensor Ultrasonik dan akan menyala apabila dalam jarak $10 \mathrm{~m}$ sebelum melintasi tikungan jalan ada kendaraan yang akan melintas.

\section{Pendahuluan}

Indonesia merupakan Negara berkembang, sebagai negara yang berkembang Indonesia masih tertinggal dalam hal transportasi umum karena sebagian besar warga Indonesia lebih memilih menggunakan kendaraan pribadi daripada kendaraan umum. 
Sebagian besar, kendaraan pribadi yang digunakan warga Indonesia adalah kendaraan roda dua. Menurut data korps lalu lintas Kepolisian Negara Republik Indonesia menyebutkan bahwa pengguna motor di Indonesia adalah sebanyak 86,253 juta unit dan terus mengalami peningkatan setiap tahun. Semakin banyak pengendara roda dua maka hal ini juga dapat menyebabkan banyaknya kecelakaan yang terjadi.

Peneliti melihat, beberapa kecelakaan terjadi di persimpangan jalan. Di daerah pemukiman padat ataupun perumahan banyak terdapat persimpangan sehingga banyak tikungan tajam yang berbahaya bagi pengguna jalan baik yang bermotor maupun tidak. Tikungan tajam adalah tikungan yang mempunyai sudut lancip dengan tingkat kesulitan saat kendaraan melintasi jalan. (Kresno,2008)

Pada tikungan tajam sering terjadi kecelakaan kendaraan. Kecelakaan tersebut terjadi akibat dari kesalahan manusia sendiri. Kecelakaan terjadi bukan pada saat jalan dalam keadaan padat kendaraan justru pada saat yang tidak padat kendaraan. Kondisi jalan yang tidak padat kendaraan memicu pengendara untuk mengendara dengan kencang. Kecelakan disebabkan oleh kendaraan yang melaju pada kecepatan tinggi saat akan melintas di tikungan jalan. Selain itu, pengendara juga ingin mendahului kendaraan saat akan melewati tikungan. Pengendara tidak tahu pada saat bersamaan kendaraan pada arah yang berlawanan sedang melaju kencang yang secara tiba-tiba membuat kaget pengendara yang akan melewati tikungan, sehingga terjadi kecelakaan. Meskipun selama ini mungkin kecelakaan yang terjadi tidak terlalu parah dan dianggap sepele namun hal ini juga dapat menimbulkan konflik di masyarakat yang seharusnya tidak terjadi.

Berdasarkan dari latar belakang diatas, maka penulis memberikan solusi dengan merancang alat peringatan untuk mencegah kecelakaan di tikungan jalan dengan menggunakan Arduino UNO.

\section{Metode Penelitian}

\section{A. Diagram Alir Penelitian}

Pada Gambar 1 merupakan alur penelitian yang dilakukan oleh peneliti. Dari gambar tersebut dapat dijelaskan ketika melakukan penelian hal pertama yang harus dilakukan adalah mencari referensi atau studi literatur untuk mengetahui langkah dan bagaimana memulai penelitian. Setelah mendapatkan referensi yang diharapkan peneliti melakukan analisa terhadap system yang akan dirancang. Pengujian merupakan tahap paling penting. Pada tahap ini, peneliti dapat mengetahui hasil dari rancangan yang telah dibuat. Jika sesuai maka pengujian selesai dan peneliti menyusun laporan dan dokumentasi. Namun, jika tidak sesuai maka peneliti menguji kembali kesalahan yang terjadi pada alat yang dirancang atau pada aplikasi yang dibangun. Setelah proses pengujian selesai maka peneliti akan mulai menyusun laporan dan dokumentasi untuk membuktikan hasil penelitian yang dilakukan. Setelah semu tahapan dilakukan maka penelitian selesai dilakukan.

\section{B. Diagram Desain Perangkat Keras}

Pada Gambar 2 menjelaskan bahwa ketika memulai dengan menyalakan powerbank apabila sensor tidak menerima input maka lampu LED tidak akan menyala atau mati. Apabila sensor ultrasonik menerima input dengan ada yang melintasi sensor tersebut maka LED berwarna merah akan menyala pada arah yang berlawanan dan LED hijau akan mati pada arah yang berlawanan dan begitupun sebaliknya.

\section{Rancangan Alat Peringatan di Tikungan Jalan}

Pada Gambar 3, cara kerja dari alat peringatan di tikungan jalan berbasis Arduino UNO ini menggunakan sensor Ultrasonik HCSR-04 untuk mendeteksi keberadaan kendaraan berdasarkan kendaraan yang melintasi sensor tersebut. Apabila kendaraan melewati sensor yang telah dipasang pada jarak 10 m sebelum melintasi tikungan tersebut maka LED warna hijau akan menyala dan pada arah yang berlawanan LED berwarna merah akan menyala. 


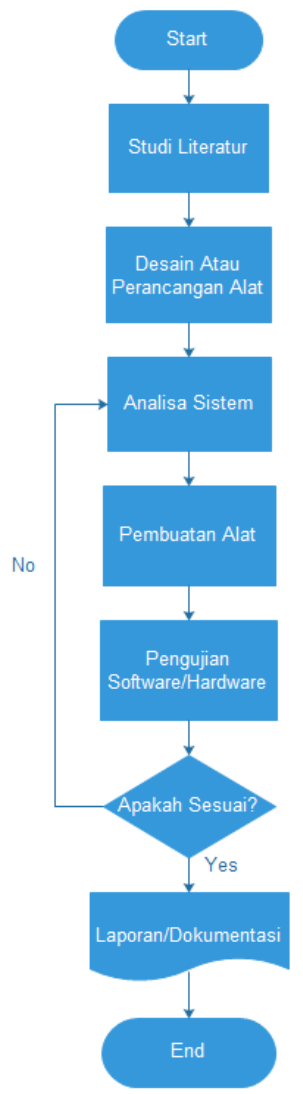

Gambar 1. Diagram Alir Penelitian

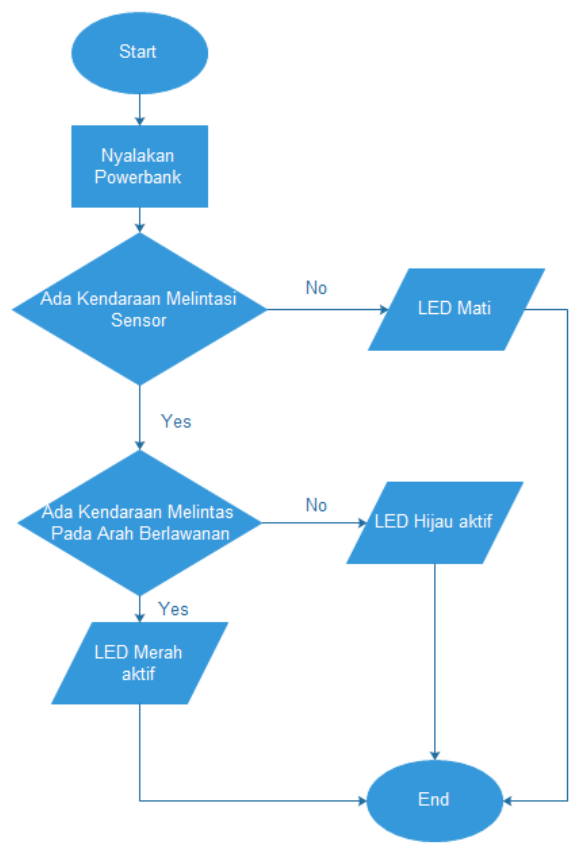

Gambar 2. Diagram Desain Perangkat Keras

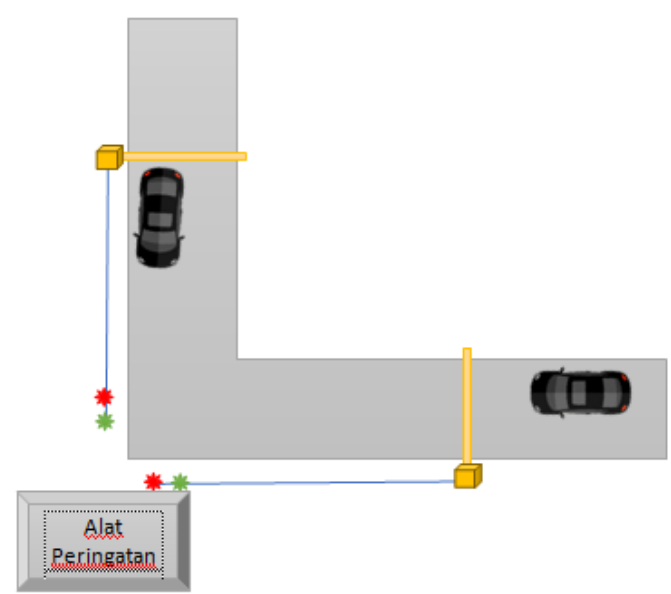

Gambar 3. Rancangan Alat Peringatan di Tikungan Jalan

\section{Hasil dan Pembahasan}

Objek penelitian ini dilakukan di 3 lokasi yaitu : Jalan RT 02 RW 01 Desa Blado Kulon, Jalan RT 03 RW 01 Desa Blado Kulon, Jalan RT 06 RW 01 Desa Blado Kulon.

Proses pengujian dilakukan dengan mengamati kinerja alat saat dipasang tepat pada tikungan jalan. Pengujian ini meliputi pengujian beberapa alat yaitu ; Pengujian LCD, pengujian Sensor ultrasonik, serta pengujian pada LED dan Buzzer.

\section{A. Pemasangan Posisi Rangkaian Master}

Pada hal ini, posisi rangkaian master terletak tepat pada tikungan jalan. Rangkaian ini dipasang dengan posisi kedua rangkaian LED menghadap pada jalan yang akan dilalui oleh pengendara agar pengendara dapat memperhatikan isyarat lampu yang akan memberikan peringatan apakah ada kendaraan yang akan melintas pada arah yang berlawanan. Berikut ini merupakan gambar dimana rangkaian master dipasang. 


\section{JEETech}

Journal Of Electrical Engineering And Technology

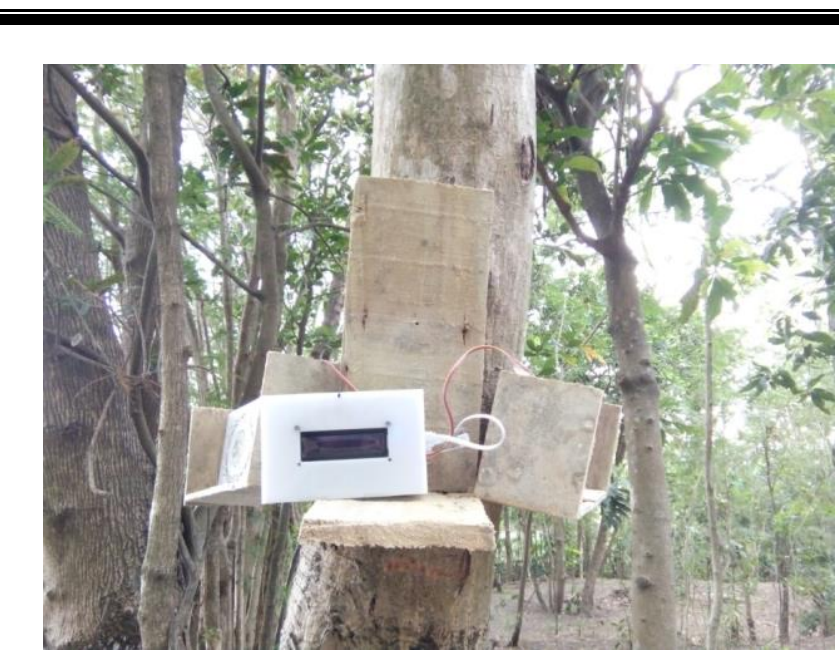

Gambar 4. Pemasangan Posisi Rangkaian Master

\section{B. Tampilan LCD}

Berikut ini merupakan tampilan layar LCD pada saat sistem mulai dinyalakan.

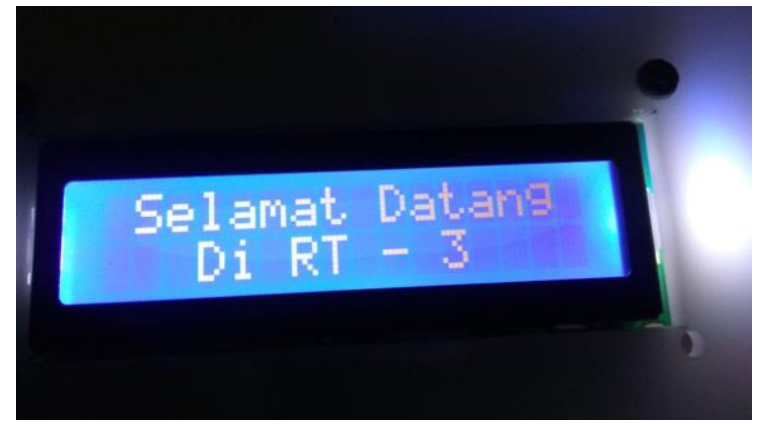

Gambar 5. Tampilan Awal Layar LCD

Pada Gambar 6 layar LCD menampilkan "Selamat Datang di RT 03" karena alat ini dipasang pada tikungan jalan yang terletak di RT 03. Sedangkan Pada Gambar 6 layar LCD menampilkan "Hati-hati dijalan" karena sensor telah menerima input yaitu ada yang melintasi sensor.

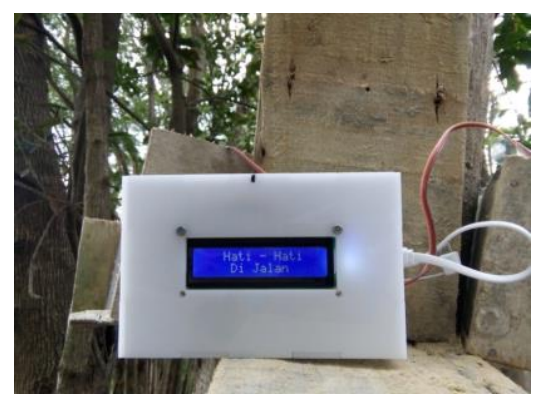

Gambar 6. Tampilan Layar LCD Saat Sensor Menerima Input

\section{Tampilan LED}

Berikut ini merupakan tampilan LED pada saat bagian slave menerima input dari sensor yang dipasang $10 \mathrm{~m}$ sebelum tikungan.

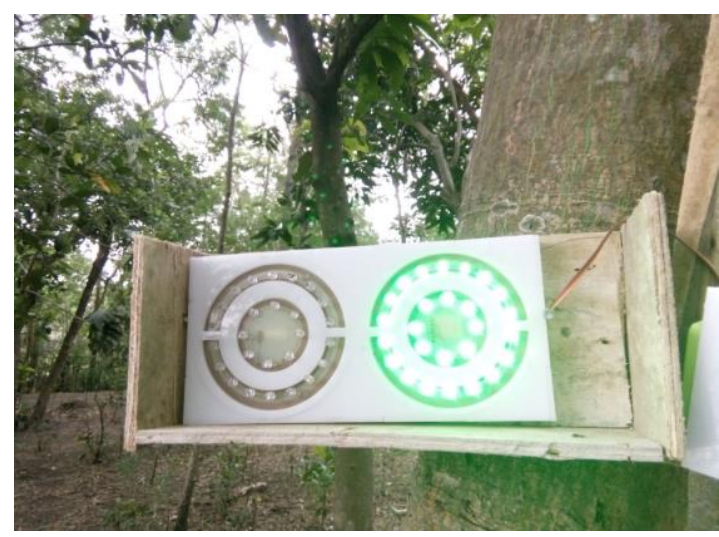

Gambar 7. Tampilan LED Hijau

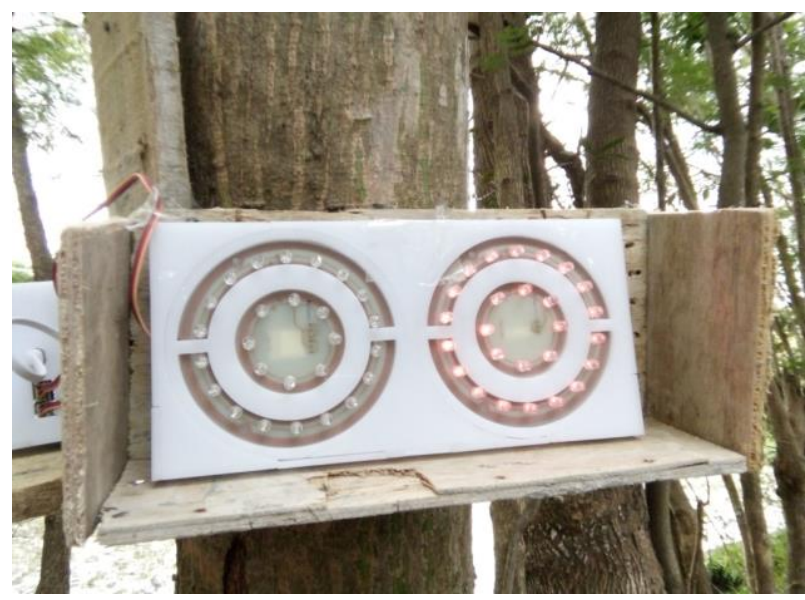

Gambar 8. Tampilan LED Merah

Pada Gambar 8 menandakan bahwa tidak ada kendaraan yang melintas pada arah berlawanan. Sedangkan Gambar 7 menandakan bahwa ada kendaraan yang melintas pada arah berlawanan.

\section{Tabel Pengujian}

Pada tabel 1 merupakan hasil pengujian untuk mengetahui apakah sensor dan alat bekerja sesuai dengan yang diharapkan dengan batas maksimal dari ultrasonik yaitu 500 $\mathrm{cm}$ 


\begin{tabular}{|c|l|l|l|}
\hline \multicolumn{5}{|c}{ Tabel 1 Pengujian Sensor Ultrasonik } \\
\hline No & $\begin{array}{c}\text { Jarak } \\
\text { Ultrasonik }\end{array}$ & Indikator & Keterangan \\
\hline 1 & $100 \mathrm{~cm}$ & Nyala Merah & Berhasil \\
\hline 2 & $200 \mathrm{~cm}$ & Nyala Merah & Berhasil \\
\hline 3 & $300 \mathrm{~cm}$ & Nyala Merah & Berhasil \\
\hline 4 & $400 \mathrm{~cm}$ & Nyala Merah & Berhasil \\
\hline 5 & $500 \mathrm{~cm}$ & Nyala Merah & Berhasil \\
\hline Presentase Keberhasilan & $100 \%$ \\
\hline
\end{tabular}

Untuk megetahui batas maksimal dari Bluetooth maka dilakukan pengujian, hasilnya bisa dilihat pada tabel 2

\begin{tabular}{|c|c|c|c|}
\hline 2 & A & Nyala Merah & Berhasil \\
\hline 3 & A & Nyala Merah & Berhasil \\
\hline 4 & A & Nyala Merah & Berhasil \\
\hline 5 & B & Nyala Merah & Gagal \\
\hline 6 & B & Nyala Merah & Berhasil \\
\hline 7 & B & Nyala Merah & Gagal \\
\hline 8 & B & Nyala Merah & Berhasil \\
\hline 9 & A & Nyala Hijau & Gagal \\
\hline 10 & B & Nyala Merah & Berhasil \\
\hline \multicolumn{2}{|c|}{ Presentase Keberhasilan } & $70 \%$ \\
\hline
\end{tabular}

Tabel 2 Pengujian jarak Jangkauan Maksimal Bluetooth

\begin{tabular}{|c|l|l|}
\hline No & \multicolumn{1}{|c|}{ Jarak Bluetooth } & \multicolumn{1}{c|}{ Keterangan } \\
\hline 1 & 3 meter & Terhubung \\
\hline 2 & 5 meter & Terhubung \\
\hline 3 & 8 meter & Terhubung \\
\hline 4 & 11 meter & Terputus \\
\hline 5 & 15 meter & Terputus \\
\hline
\end{tabular}

Tabel 3 Pengujian Dari Beberapa Arah Berlawanan

\begin{tabular}{|c|c|c|c|}
\hline $\begin{array}{c}\text { Pengujian ke } \\
-\end{array}$ & $\begin{array}{c}\text { Dari } \\
\text { Arah }\end{array}$ & $\begin{array}{c}\text { Indikator / } \\
\text { Isyarat }\end{array}$ & Keterangan \\
\hline 1 & A & Nyala Merah & Berhasil \\
\hline
\end{tabular}

\section{Kesimpulan}

Kesimpulan yang didapat dari kegiatan diatas adalah :

1. Sensor ultrasonik dapat bekerja dengan baik hingga jarak $500 \mathrm{~cm}$ dengan presentasi keberhasilan $100 \%$ dalam pengujian. Hal ini dikarenakan jarak jangkauan maksimal sensor ultrasonik adalah $500 \mathrm{~cm}$.

2. Bluetooth hanya dapat bekerja hingga jangkauan maksimal $10 \mathrm{~m}$ tanpa halangan.

3. Dalam pengujian dari beberapa arah yang berlawanan 7 diantara 10 pengujian berhasil sedangkan 3 pengujian gagal. Pengujian gagal tersebut dapat disebabkan karena objek kurang mengenai sensor atau kabel untuk LED terpasang longgar.

4. Keadaan cahaya tidak mempengaruhi dalam kinerja sensor Ultrasonik 


\section{Daftar Pustaka}

Daftar pustaka mengikuti format IEEE seperti terlihat di bawah ini. Untuk memudahkan sangat dianjurkan untuk menggunakan Endnotes Program ataupun Mendelay di dalam mengatur daftar pustaka.

[1] Kresno, Kuncoro, "Prototype Pendeteksi Kendaraan yang Melintas Dari Arah Berlawanan Pada Tikungan Tajam Berbasis Mikrokontroller AT89S51,". Universitas Negeri Yogyakarta, 2017.

[2] Setiawan, Afrie. 2011. 20 Aplikasi Mikrokontroller ATMega 8535 \& ATMega 16 Menggunakan BascomAVR. Yogyakarta.

[3] Eritha, Fadila N. 2015. Implementasi Bluetooth HC05 Untuk Mengurangi Tingkat Kecelakaan Pada
Pengendara Sepeda Motor.

[4] Andayani, Martalia. 2016. Kalibrasi sensor Ultrasonik HC-SR04 Sebagai Sensor Pendeteksi Jarak Pada Prototipe Sistem Peringatan Dini Banjir. Universitas Negeri Jakarta.

[5] A Setiyawan, N Hikmah, I Marzuki, "Prototype Alat Untuk Mengukur pH, Suhu, Dan Kadar Kekeruhan Air Tambak Untuk Budidaya Udang Vaname (Litopenaeus Vannamei) Menggunakan Arduino Uno," in Jurnal Informatika Upgris, 2020. 